\title{
DEVELOPMENT OF WEB GAME LEARNING MATERIALS FOR PRIMARY SCHOOL STUDENTS
}

\author{
Wahyudi*1 $^{1}$, Marisa Ambarwati ${ }^{2}$, Endang Indarini ${ }^{3}$ \\ ${ }^{1,2,3}$ Universitas Kristen Satya Wacana
}

\section{Article Info \\ Article history: \\ Received June 15, 2019 \\ Revised Sept 21, 2019 \\ Accepted Sept 26, 2019}

\section{Keywords:}

Concept Attainment Model, Mathematical Communication, Prior Mathematical Knowledge

\begin{abstract}
The purpose of this study is to develop a web game learning materials to improve problem-solving skills in two-dimensional figure. R\&D with the ASSURE development model was chosen as the research method which consists of 6 steps, namely1) analyzing learners, 2) stating objectives, 3) selecting method, media, and materials, 4) utilizing media and materials, 5) requiring learner participation, 6) evaluating and revising. The validity of the product was assessed by the experts usingthe expert validation sheets. The practicality of the product was tested by a limited trial of 10 students followed by interviews to see students' responses. The Product effectiveness was seen from one class trial with one group pretest-posttest design and the results were analyzed using the Paired-Samples T-Test. The results of this study were in the form of web-based game learning media, aiming to improve problem-solving skills regarding two-dimentional figures 1 . The learning media were proven valid based on the expert testing of media, material, and learning tests. Learning media were also proven practical based on the results of interviews by 10 students. Learning media were proven effective based on the T-Test paired samples taken from the results of the pretest and post test.
\end{abstract}

Copyright $(2019$ IKIP Siliwangi. All rights reserved.

\section{Corresponding Author:}

Wahyudi,

Departement of Mathematics Education,

Universitas Kristen Satya Wacana,

Jl. Diponegoro No.52-60, Salatiga, Central Java 50711, Indonesia.

Email: yudhi@staff.uksw.edu

\section{How to Cite:}

Wahyudi, W., Ambarwati, M., \& Indarini, E. (2019). Development of web game learning materials for primary school students. Infinity, 8(2), 199-208.

\section{INTRODUCTION}

Along with the progress of times, the development of technology has increasingly affected many realms of life including education that now has widely utilized technology as a means of communication among teachers and students (Bainbridge, 2013; Bates, 2005; Mumtaz, 2000). Education as an information activity, and can be disseminated to the next generation of a nation through information technology, is able to turn challenges into opportunities, and master various methods in solving problems (Kalelioglu \& Gülbahar, 2014). Problem solving is one of the two skills a person must have to face the future (Pomalato, 2005). This skill is considered important as to make a decision, one must first understand what problems they face in order to find a way out. 
Thus, problem solving skills need to be developed since the early age on. This can be done by starting to familiarize child to solve problems, one of them through learning activities at school. Mathematics is one of the subjects that can facilitate students to hone their problem solving skills (Schoenfeld, 2016). However, mathematics is often still considered a difficult and boring subject (Rahayu \& Afriansyah, 2015). This assumption forms a negative understanding of students in mathematics (Gazali, 2016). To eliminate this misunderstanding, the teacher as a facilitator must be able to create an interesting learning atmosphere.

However, what is happening now, there are still many teachers who teach without providing opportunities for students to learn on their own how to solve a problem. Teachers tend to give "short cuts" for granted to students. Often, the teachers keep focusing on transfering the knowledge stated on the text book instead of enhancing students' problem solving skillls by providing certain problematical cases. This is indeed out of balance because the assessment onlyconcern on cognitive abilities, while the problem solving skills are ruled out. In fact, students' ability to solve problems is important and needs to be developed.

Although some teachers have provided opportunities for students to hone their skills in solving problems, many students still feel bored with their learning activities. This is because the teacher still use the old teaching methods which are not balanced with the current demands. The teacher should be able to choose the right learning media that are in accordance with the characteristics of students. Also, , the media chosen by the teacher must also meet the requirements of good learning media.

In addition to fulfilling good media requirements, the media used must also be in line with the demands of education today, where learning has begun to be integrated with technology (Yunianta, Putri, \& Kusuma, 2019). The teacher should choose the media that is in accordance with this demand. One of the media that can be utilized is web game technology or often called online gaming. Research conducted by Newzoo, Indonesia is a country with the highest number of players playing on mobile devices and PCs. As much as 61 percent of game players in Indonesia are actively playing games on more than two platforms every month. While 46 percent of Indonesian game players are confirmed to play games on mobile devices and PCs. Considering that game users are increasing, teachers can use game as a learning medium.

Games are developed based on fun learning, where students will be faced with a number of instructions and rules of the game (Panggayudi, Suweleh, \& Ihsan, 2017). Through the instructions and rules of the game, students can find a way out and solve every problem passed in the game being played. This activity can attract students' attention and foster a great curiosity about how they can complete the game and find a way to reach the destination.

Learning using media is suitable for elementary school children, given that they are entering the phase of having great curiousity. In addition, children in elementary school are still very happy to play thus the material packaged in game form can reduce students' boredom compared to teacher-oriented learning. The purpose of this study is to develop a web game learning materials to improve problem-solving skills in two-dimensional figure. The expectation is that by using this media, students' mathematical problem solving skills especially regarding two-dimensional figure could improve. 


\section{METHOD}

\subsection{Stages of Development}

This research is a type of research development or R \& D using the ASSURE Development model (Smaldino, Lowther, Russell, \& Mims, 2008). This model is divided into 6 stages, namely: 1) analyze learners, 2) state objectives, 3) select strategi, technology, media, and materials, 4) utilize media and materials, 5) require learner participation, 6) evaluated and revise (Smaldino et al., 2008). The ASSURE model is shown in Figure 1.

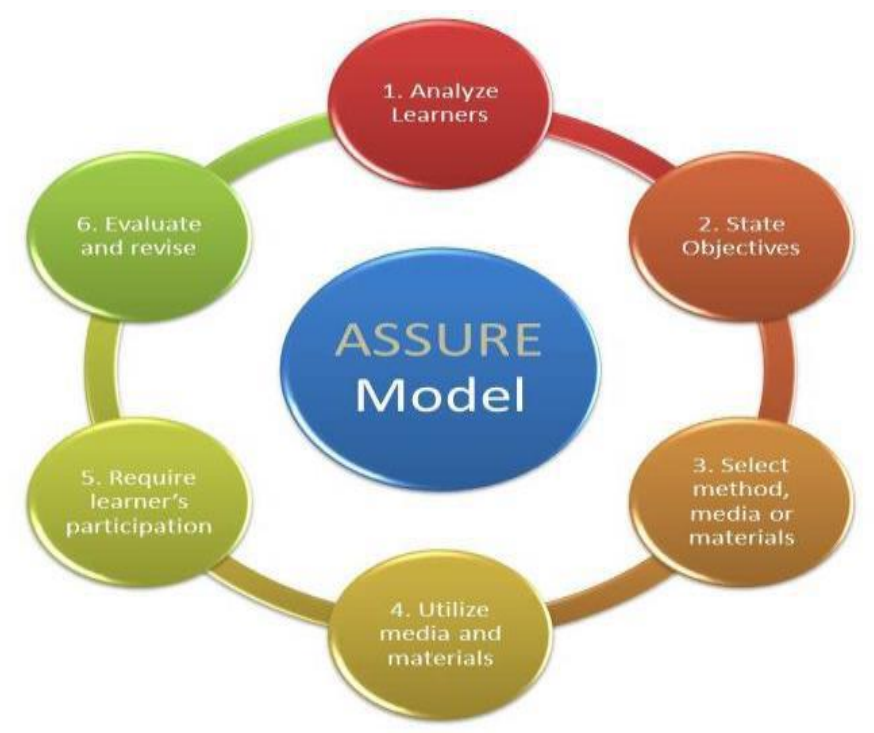

Figure 1. ASSURE development model

Based on the chart in Figure 1, the stages of ASSURE model development can be explained as follows.

\subsubsection{Analyze Learners (Analyze Students' Characteristics)}

The initial stage that needs to be done is to identify students including their characteristics, initial abilities, and learning styles. To obtain thedata, interviews will be conducted with teachers and students, and questionnaires to students are provided. These data are used as preliminary data to develop learning media thus appropriate methods and learning activities can be determined. The subjects chosen in this study were 4th grade students at SD N Sugihan 01.

\subsubsection{State Objectives (Setting Learning Objectives)}

The second stage is to set learning objectives to be achieved. Before setting learning objectives, the researchers conducted an analysis of the curriculum used in schools, Core Competencies (KI) and Basic Competencies (KD) in accordance with the revised 2013 curriculum in 2017. The learning objectives need to be determined in order to choose the correct media, regulate the learning environment that is in line with the demand objectives, determine assessment / evaluation techniques and instruments.

\subsubsection{Select Method, Media, and Materials}

The third stage in this development model is choosing methods, media, and teaching materials that will be used during the learning process. This activity needs to be done because those three components can help students achieving the learning objectives 
that have been made before. Determination of all three was based on students' characteristics and learning objectives designed.

\subsubsection{Utilize Media and Materials}

The next stage will be applying the methods, media, and teaching materials that have been chosen. Before all of them were implemented, validation / expert test (material experts, media experts, learning experts, and expert questions) has to be carried out first to see the quality and feasibility of media developed. After obtaining expert validation, the media can be used in the learning process at the chosen elementary school.

\subsubsection{Require Learner Participation}

The fifth stage was involving students in learning activities. Here, they will get learning activities that has been previously designed. The learning process will use media learning web games to help improving theirproblem solving skills. The purpose of using this media was to help students understand two-dimensional figure material using problemsolving steps.

\subsubsection{Evaluation and Revise}

After the learning media has been designed and developed, the next step is to evaluate the media used. This activity was conductedto obtain data related to the advantages and disadvantages of the media being developed. The results will be used as input to improve the media, thus it is ready to use in every school.

\subsection{Techniques and Data Collection Instruments}

The validity (feasibility), practicality, and effectiveness of the product will surely be tested. The validity of the product can be seen by means of expert judgment. Expert assessment includes learning experts, learning media experts, learning material experts and problem experts. Expert assessment data was done using a Likert scale with a range of 1-5 with criteria not good (1) to very good (5). These results were used to see the feasibility (validity) of the products produced. To see the practicality of the product carried out by a limited test to 10 students and conducted interviews to see students' responses to the products used. Effectiveness was seen from the comparison of student learning outcomes when working on the pretest and posttest questions.

\subsection{Data Analysis Technique}

Data obtained from expert assessment results (product validation) were then analyzed using percentage descriptive and categorical analysis techniques to see the feasibility of the media. Initially the results obtained from the product assessment in the form of scores were presented in the form of a closed questionnaire which was then summed and averaged between the results of the assessment from media experts, material experts, matter experts and learning experts. The score obtained was then percentage using the formula.

Note

$$
\mathrm{AP}=\frac{\text { Actual Score }}{\text { Ideal Score }} \times 100 \%
$$

AP : Percentage Number

Actual Score : Score given by expert validator

Ideal Score : Maximum score between the number of items and maximum score for each item. 
Table 1. Product Development Quality Category

\begin{tabular}{cc}
\hline Interval & Category \\
\hline $81-100 \%$ & Very good \\
$61-80 \%$ & Good \\
$41-60 \%$ & Fair \\
$21-40 \%$ & Low \\
$1-20 \%$ & Very low \\
\hline
\end{tabular}

Based on the categories (Table 1), web game learning materials is declared feasible if the average percentage reaches a high category $(\geq 61 \%)$. Practical testing was done by looking at students' responses known from the interview activities. The effectiveness test was done by comparing student learning outcomes before and after being given the pretest and posttest questions. This test will later be processed using one group pretest-posttest. Final scores before and after using the media were compared using the Paired-Sample TTest with the help of SPSS 16.

\section{RESULTS AND DISCUSSION}

\subsection{Results}

The Results should include the rationale or design of the experiments as well as the results of the experiments. Results can be presented in figures, tables, and text. The Results should include the rationale or design of the experiments as well as the results of the experiments. Results can be presented in figures, tables, and text. This study produced a webgame-based media learning product to improve problem-solving skills in twodimensional figure material. The results of media development using the ASSURE development model consisting of 6 stages are explained as follow:

\subsubsection{Analyze Learners}

Concerning students' characteristics of learning styles, it was found that 19 students (73\%) had a visual learning style. This data will be used as the basis for determining the appearance and facilities available in the web game. Other aspects measured was the students' initial ability to construct two-dimensional figure material, the initial ability to operate a computer. The results obtained from the analysis of the three aspects can be seen in Table 2.

Table 2. Results of Analyze Learners

\begin{tabular}{clcccc}
\hline \multirow{2}{*}{ No } & \multicolumn{1}{c}{ Competency } & \multicolumn{3}{c}{ Total } & \multirow{2}{*}{ Total } \\
\cline { 2 - 4 } & Not Good & Less Good & Good & \\
\hline 1 & $\begin{array}{l}\text { Understanding of two-dimensional } \\
\text { figure material }\end{array}$ & 21 & 2 & 3 & 26 \\
2 & Able to operate a computer & 2 & 4 & 20 & 26 \\
\hline
\end{tabular}

Based on Table 2, it was implied that most students (73\%) agreed that they had a visual learning style. As much as $(81 \%)$ students showed disagreement in understanding two-dimensional figure material and as much as (77\%) agreed of being able to operate a computer.

Meanwhile, the interview results revealed that half of the students in the class claimed to be bored with math because they were only fixated on the book. They were given too many questions without any fun activities. This then impacted on student learning outcomes. In addition, minimum use of media was also one of the reasons why 
students were not interested in learning. This was then used as the basis for developing webgame-based learning media with the aim of putting studentsin a pleasant atmosphere. Besides that, it can help them improve their problem solving abilities.

\subsubsection{State Objectives}

After analyzing the students' initial abilities, the next step was to determine the learning objectives. Before the learning objectives were determined, basic competencies (KD) were first determined and also learning indicators can be formulated in Table 3.

Table 3. Basic Competencies and Indicators

\begin{tabular}{ll}
\hline \multicolumn{1}{c}{ Basic Competencies } & \multicolumn{1}{c}{ Indicator } \\
\hline $\begin{array}{l}\text { Explain and determine the circumference } \\
\text { and area of a square, a rectangle, and a } \\
\text { triangle and a power of two with a square }\end{array} \begin{array}{l}\text { Describe the formula around and area of a square, } \\
\text { root. }\end{array}$ & $\begin{array}{l}\text { rectangle and triangle. } \\
\text { Calculate the area and circumference of a square, } \\
\text { rectangle and triangle. }\end{array}$ \\
& $\begin{array}{l}\text { Solve problems related to area and circumference } \\
\text { of square, rectangle and triangle. }\end{array}$ \\
\cline { 2 - 2 } $\begin{array}{l}\text { Re-prove the calculation relating to the area and } \\
\text { circumference of a square, rectangle and triangle. }\end{array}$ \\
\hline $\begin{array}{l}\text { Resolve a problem related to the } \\
\text { circumference and area of a square, } \\
\text { rectangle, and triangle including involving } \\
\text { the power of two with a square root. }\end{array}$ & $\begin{array}{l}\text { Design the model according to the area and } \\
\text { circumference of the building that has been } \\
\text { calculated. }\end{array}$ \\
\hline
\end{tabular}

The next step was formulating the leaarning objectives based on the basic competency and its indicators. The following is the formulation of the objectives of mathematics learning in the material of two-dimensional figure: (1) By playing the game, students can describe the formula around and the area of a square, rectangle and triangle correctly; (2) By playing the game, students can calculate the area and circumference of the square, rectangular and triangle shapes in the game correctly; (3) By playing games and designing models, students can solve problems related to the area and circumference of square, rectangle and triangle correctly; (4) With group activities, students can prove again the calculations related to the area and circumference of the square, rectangle and triangle; (5) With group activities, students can design models according to the area and circumference of the building that has been calculated.

\subsubsection{Select Method, Media, and Materials}

The next stage in the ASSURE development method was to choose methods, media and teaching materials. The method chosen in thelearning activities were lectures, discussions, assignments and questions and answers. The selected medi was webgamebased learning media and teaching materials used were student books and mockups to check students' understanding after playing using webgame media.

\subsubsection{Utilize Media and Materials}

After drafting in stage 3, the next step was to arrange the design of learning activities. The tools needed included Lesson Plans, Student Worksheets, Media (Webgame learning media). Before being used, the devices underwent series of expert tests such as media, materials, questions and learning experts. The following results of the expert test are presented in Table 4. 
Table 4. Expert Test Results

\begin{tabular}{clcccc}
\hline No & Indicator & Ideal Score & Actual Score & AP & Category \\
\hline 1 & Learning materials & 60 & 48 & $80 \%$ & Good \\
2 & Learning materials & 70 & 52 & $72.4 \%$ & Good \\
3 & Question & 55 & 41 & $74.5 \%$ & Good \\
4 & Learning & 60 & 49 & $81.7 \%$ & Very Good \\
\hline
\end{tabular}

Based on the media eligibility criteria that have been developed, the developed media fell into good and very good category (AP > 61\%) thus the media were feasible to use. Furthermore, through student responses, the media were seen practical. Interviews were conducted with 10 students about what they thought after using webgame media in learning. The interview results can be seen in Table 5.

Table 5. Student Response Results

\begin{tabular}{clc}
\hline No & \multicolumn{1}{c}{ Question } & Score \\
\hline 1 & What do you think about using web game media in learning? & 10 \\
2 & Are you interested in participating in learning using web game media? Why? & 10 \\
3 & By learning using web games, can you better understand the material easily? Why? & 7 \\
4 & What do you think about using web game media to solve problems related to flat, & \\
& rectangular, and triangular material? & 8 \\
5 & Do you prefer to use web media games in learning? & 10 \\
& & Total \\
& Percentage & 45 \\
\hline
\end{tabular}

Based on the results of student responses after using the webgame media, $90 \%$ students stated that it was very good, thus it can be concluded that the webgame-based media were very helpful for the students to comprehend the two-dimensional figure material.

\subsubsection{Require Learner Participation}

The next step was to involve students in learning activities. Students must be actively involved in learning to be able to see the effectiveness of the media that has been developed in order to achieve learning goals. Learning activities were carried out in accordance with the designs that have been made before. Webgame display that can improve problem solving capabilities can be seen in Figure 2a, Figure 2b, Figure 2c, and Figure 2d.

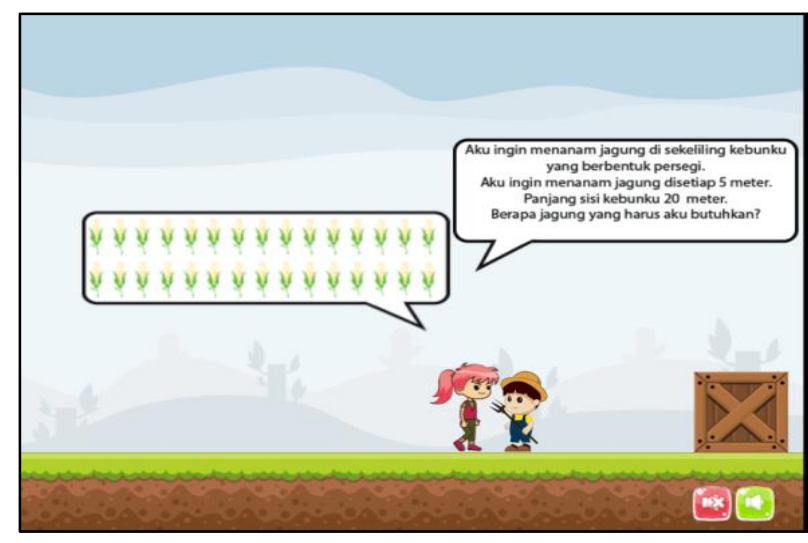

Figure 2a. Example of game display at the stage of understanding problem.

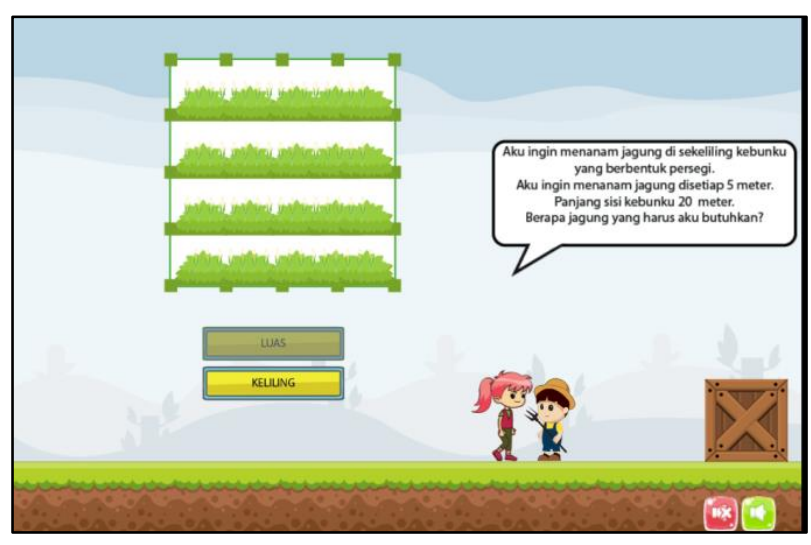

Figure 2b. Example of game display at the stage of planning completion 


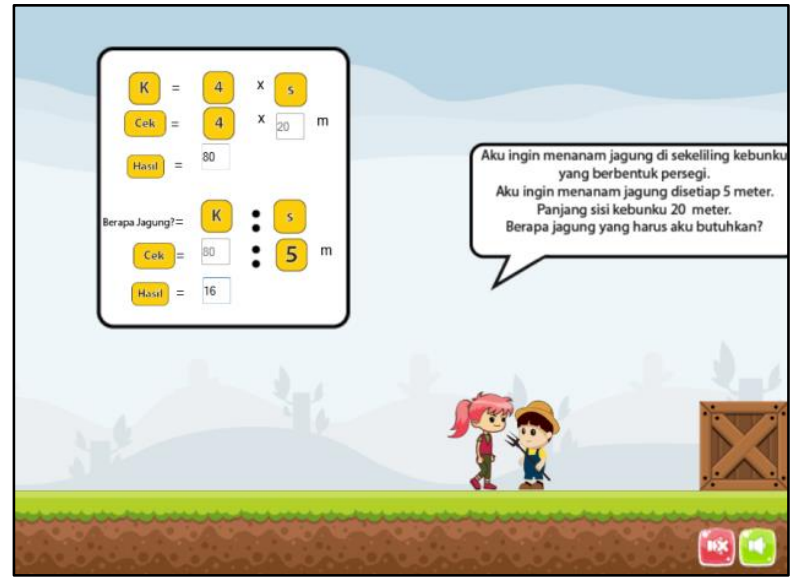

Figure 2c. Example of game display implementing completion

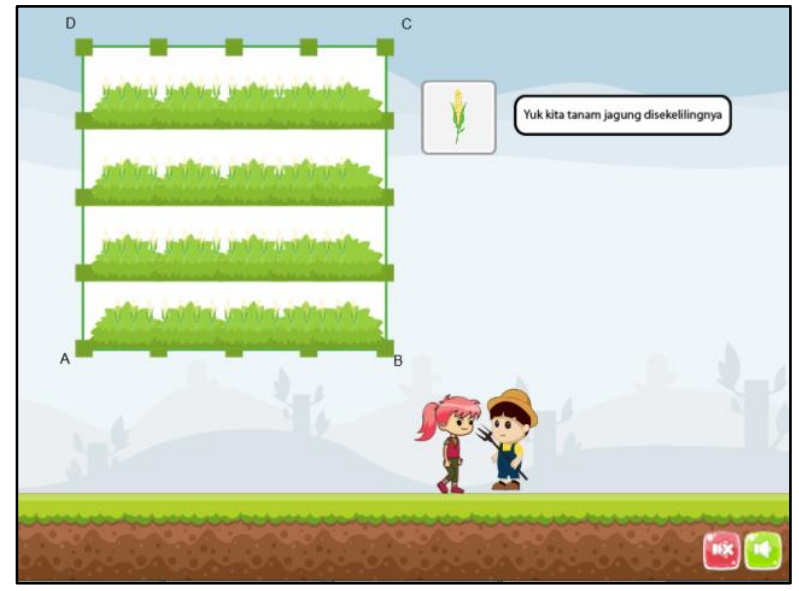

Figure 2d. Examples of game display at the stage of look again.

The effectiveness of the model can be seen from the results of the pretest compared with the results of the posttest. Based on the Paired Samples test results, the results obtained show the Sig. (2-tailed) equal to 0.000 or less than 0.05 , it can be concluded that there are significant differences between learning outcomes.

\subsubsection{Evaluation and Revise}

Based on the results of expert testing and implementation of learning there were several things that must be revised and evaluated. In the media section, there were still a lot of typospunctuation, and unclear game instructions. The display of the call out was also too monotonous, In addition to learning devices such as lesson plans, problems in the selected Problem Based Learning learning model were not shown.

\subsection{Discussion}

The percentage shown from the results of the evaluation by material experts was $80 \%$ and hence the media were considered 'very good' to use. The essence of learning mathematics using logic and thinking emphasized in the use of webgame learning media produced a level of product validity that is in accordance with the opinion (Suhendri, 2011). Then based on the results of evaluations by media experts, the percentage was $72.4 \%$, which is considered 'good' to use. Webgame-based learning media in twodimensional figure material has the same benefits as opinions (Sanaky, 2009), which can attract student learning interest and can provide varied methods and media. Then based on the results of the evaluation by the expert of questions, the percentage obtained was $74.5 \%$, showing that it was actually 'very good' to use. Finally, based on the results of evaluations by learning experts, the percentage of results was $81.7 \%$, the score was concluded 'very good' to use.

Based on the results of interviews conducted by researchers, the percentage was $90 \%$. The score that researchers gained was very good, thus it can be concluded that students were helped in understanding two-dimensional figure material and gained practicality when using webgame-based media. The pre-test results were $57.05 \%$ and after using the media, it changed into $83.9 \%$ based on post-test data. This has proven to be effective in improving problem solving skills in students. The pre-test and post-test data obtained were tested by Paired Samples T Test with the results of the data showing the Sig. 
(2-tailed) equals 0,000 or less than 0.05 , thus there are significant differences between the learning outcomes in the pre-test and post-test data.

Based on the results of research that has been carried out web game learning materials to improve the ability to solve problems in two-dimensional figure material can improve problem solving abilities. This can be seen from students being happy when using instructional media to help them understand two-dimensional figure material. Mathematics learning is a learning activity designed by teachers to develop students' creative thinking, and to help students improving their ability to build new knowledge as an effort to improve mastery of mathematical material (Sutanto, 2016). At first the students' ability to understand the material of two-dimensional figure was still low, and students were also still confused to understand the material if two-dimensional figure. This is because students were bored with learning activities that werer fixated on books without any interesting activities. In addition, the lack of media used by the teacher when learning takes place, is also one of the reasons for the decline in student interest of learning. Media-based learning activities also gave students the opportunity to learn math from the contextual problems in mission-solving activities. This made them challenged to continue to find solutions to problems in the mission. This was what gave students the opportunity to learn mathematics from solving problems in a structured and challenging activity. This was in accordance with the research results of Darling-Hammond (2008), where the teacher should always give students the opportunity to solve the problem in a structured and challenging way.

However, there are still constraints in the use of media games. One of them is that some students have not been able to use this media games due to the lack of ICT skills among them. They focuses on learning using the application so that problem solving skills are not maximally improved. In additionn, it takes a good internet network so that the web application can run well and hence the students can learn optimally and smoothly. It also needs teachers who master this application, so that they can guide students to study with this web application.

\section{CONCLUSION}

Based on the results of the research and discussion that have been done, it can be concluded that the webgame-based learning media is valid, practically seen from the expert test and student responses after using webgame media and effective to be used in classroom learning activities seen from student learning outcomes that have improved before the pretest and after posttest.

Based on the results of the study, it is recommended that teachers can use creative media that utilize technology so that students become accustomed to using computers or laptops not only to play but also enrich their insights by visiting the webgmae link "Adventure of Risa". In addition, using media web games students can distinguish differences after using webgame-based learning media with learning that is usually done in class. The teacher can also compare which learning is better, without learning media or by utilizing learning media.

\section{ACKNOWLEDGEMENTS}

We gratefully acknowledge the useful comments of Dr. Suryasatriya Trihandaru, M.Sc. and Mozes Kurniawan, M.Pd lecturer in Universitas Kristen Satya Wacana. Gratefully acknowledge for Universitas Satya Wacana who has provided financial support and facilities for learning facilities in the classroom. 


\section{REFERENCES}

Bainbridge, W. S. (Ed.). (2013). Converging technologies for improving human performance: Nanotechnology, biotechnology, information technology and cognitive science. US: Springer Science \& Business Media.

Bates, A. T. (2005). Technology, e-learning and distance education. London: Routledge.

Darling-Hammond, L. (2008). Teacher learning that supports student learning. Teaching for intelligence, 2(1), 91-100.

Gazali, R. Y. (2016). Pengembangan bahan ajar matematika untuk siswa SMP berdasarkan teori belajar ausubel. Pythagoras: Jurnal Pendidikan Matematika, 11(2), 182-192.

Kalelioglu, F., \& Gülbahar, Y. (2014). The Effects of Teaching Programming via Scratch on Problem Solving Skills: A Discussion from Learners' Perspective. Informatics in Education, 13(1), 33-50.

Mumtaz, S. (2000). Factors affecting teachers' use of information and communications technology: a review of the literature. Journal of information technology for teacher education, 9(3), 319-342.

Panggayudi, D. S., Suweleh, W., \& Ihsan, P. (2017). Media Game Edukasi Berbasis Budaya Untuk Pembelajaran Pengenalan Bilangan pada Anak Usia Dini. MUST: Journal of Mathematics Education, Science and Technology, 2(2), 255-266.

Pomalato, S. W. D. (2005). Pengaruh Penerapan Model Treffinger dalam Mengembangkan Kemampuan Kreatif dan Pemecahan Masalah Matematika Siswa SMP. Unpublished Dissertation. Bandung: SPS UPI (Sekolah Pascasarjana, Universitas Pendidikan Indonesia).

Rahayu, D. V., \& Afriansyah, E. A. (2015). Meningkatkan kemampuan pemecahan masalah matematik siswa melalui model pembelajaran pelangi matematika. Mosharafa: Jurnal Pendidikan Matematika, 4(1), 29-37.

Sanaky, H. A. (2009). Media Pembelajaran. Yogyakarta: Safirina Insania Press.

Schoenfeld, A. H. (2016). Learning to think mathematically: Problem solving, metacognition, and sense making in mathematics (Reprint). Journal of Education, 196(2), 1-38.

Smaldino, S. E., Lowther, D. L., Russell, J. D., \& Mims, C. (2008). Instructional technology and media for learning. New Jersey: Pearson Merril Prentice Hall Inc.

Suhendri, H. (2011). Pengaruh kecerdasan matematis-logis dan kemandirian belajar terhadap hasil belajar matematika. Formatif: Jurnal Ilmiah Pendidikan MIPA, 1(1), 29-39.

Sutanto, A. (2016). Teori Belajar dan Pembelajaran. Jakarta: Prenada Media Group.

Yunianta, T. N. H., Putri, A., \& Kusuma, D. (2019). Development and comparison of mathematic mobile learning by using exelearning 2.0 program and MIT inventor 2. Infinity Journal, 8(1), 43-56. 